\title{
Entertaining Strangers: Providing for the Development Needs of Part-Time Faculty
}

\author{
Patricia Hanrahan Valley \\ Embry-Riddle Aeronautical University
}

For institutions of higher education that have increasingly relied upon part-time faculty members to meet the needs of a rapidly changing society, the challenge has been to provide adequate preparation and development opportunities for these instructors, many of whom have never taught before. This study investigated the characteristics of the part-time faculty, the extent to which they believed they had been oriented by the institution to assume their teaching roles, and their reported need for selected professional development activities at Embry-Riddle Aeronautical University's Extended Campus, an institution employing more than 2,800 adjuncts. The data provided by the needs assessment were instrumental in developing programs for part-time faculty development.

\section{The Use of Part-Time Faculty in Higher Education}

The dawn of the 21 st century has brought increasing concerns to higher education. Breneman (2002) noted that the recession in the early 2000s posed threats to an under-funded system and challenged the nation's commitment to accessibility for all qualified students as college tuition costs rose and student debt increased. Change, adaptation, and caution have characterized many institutions of higher education's approaches to these challenges. The continued call for educational reform and increased accountability has stimulated renewed emphasis on the quality of teaching at the undergraduate level while resources were $d$ windling. 
Within this shifting context, institutions of higher education have continued to employ a large number of part-time faculty to teach primarily undergraduate courses. As the number of nontraditional students has continued to increase and institutions have adapted their missions and programs to meet the demands of the market, changing patterns in academic employment have been redefining faculty roles. The demand for new degree programs has created more need for specialized faculty, and at the same time budgets have been leaner and faculty have been called upon to bring more varied qualifications and preparation to the academy. The primary reasons for the growing numbers of part-time faculty have been increases in student enrollment and in the number of programs offered, along with static revenue.

Colleges and universities have continued to employ a large number of part-time faculty to teach primarily undergraduate courses. Roueche, Roueche, and Milliron (1995) reported that part-time faculty did approximately $45 \%$ of all teaching in higher education. Institutions with large extension programs, such as Nova Southeastern University, University of Phoenix, University of Maryland's University College, and Embry-Riddle Aeronautical University employ primarily part-time faculty (Haeger, 1998). Roueche et al. (1995) observed that part-time faculty brought expertise from the real world to technical and vocational programs, and Fulton (2000) suggested that appropriate uses for part-time faculty within colleges and universities exist that "enhance program quality and... provide a variety of experiences for students" (p. 39). Fulton maintained that hiring practicing experts in specific fields (e.g., hiring a dynamic marketing executive to teach a marketing seminar) makes sense, and Jacobs (1998) noted that part-time faculty who are practitioners in their field often have access to resources and other experts that benefit the institution. They provide a link between instruction and the practices in industry.

\section{The Needs of Part-Time Faculty}

\section{The Need for Integration Into the Academic Community}

With the increasing changes in mission, programs, and personnel, a number of academic and institutional issues have surfaced that have to be addressed if colleges and universities are to effectively meet their missions. Roueche, Roueche, and Milliron (1996a) indicated that colleges and universities would have to improve the integration of the part-time faculty into the academic community as well as develop systemic plans for change that would clarify the purpose, mission, and major goals of adjunct employment and development. 
Gappa and Leslie (1993) reported that part-time faculty members were often regarded as consumable resources rather than as contributors to the health and integrity of the organization. They suggested that if part-time faculty were incorporated into the institution, they would bring greater commitment and continuity to their roles. Leslie (1998), Lyons, Kysilka, \& Pawlas (1999) and Roueche et al. (1995) stated that part-time faculty must be regarded as a vital part of the academic community, as the extent to which the institution integrates these faculty members into their organizations determines to a large degree the extent to which the institution will meet its mission.

\section{The Need for Improved Working Conditions}

Some part-time faculty members have experienced what they believe to be less than satisfactory working conditions. Leslie (1998) reported that "...the global picture of part-time faculty attitudes is one of competence, high morale, and a healthy level of professional engagement. But pockets of discontent exist" (p. 4). Leslie concluded that the general sources of dissatisfaction for part-time faculty were working conditions and institutional culture. Conditions such as low pay, no benefits, lack of office space, and little job security coupled with minimal status within the department or college separate the part-time instructor from the full-time faculty, create inequity, and damage the institution.

The American Federation of Teachers (2002) recommended standards that would equitably adjust pay scales, provide for adjunct evaluation, establish an adjunct promotion system, and compensate part-timers for office hours and committee service. Leslie (1998) relayed that

... the effectiveness and validity of the whole higher education enterprise is entangled in the question of what faculty do, how their work and careers are constructed, and whether they can achieve the ends that society wants from its colleges and universities. (p. 6)

\section{The Need for Faculty Development}

The development of the part-time faculty is essential if the institurions that employ them are to foster effective teaching and learning. As part-time faculty have become an integral part of teaching and learning at many institurions, supplying students with a wealth of knowledge from industry and pernitting greater fexibility in class scheduling, the challenge of providing support and development that enhances faculty effecriveness has increased. 
Eble and McKeachie (1985) defined faculty development as "programs to promote faculty growth, to help faculty members acquire knowledge, skills, and sensitivities" (p. 11). Gaff (1975) described faculty development as activities that further the instructional, professional, and personal growth of faculty members. Faculty development programs vary in mission, although the majority of programs for part-time faculty emphasize instructional development as a means of improving teaching and learning. Instructional development has been defined as "programs that facilitate student learning, prepare learning materials, and redesign courses" (Eble \& McKeachie, 1985, p. 11). According to Bensimon, Ward, and Sanders (2000) and Wunsch (1994), the specific goals for faculty development programs generally include orienting faculty to the culture of the university, developing a collegial atmosphere, and exposing faculty to best teaching practices.

Gappa (1984) observed that most part-time faculty members are not hired for their pedagogical knowledge, but rather for their professional competence; thus, many of them have no familiarity with college practices and procedures. Nor do they necessarily understand students' educational needs. Wyles (1998) has maintained that colleges and universities must take these factors into consideration when planning orientation and development programs, as the adjuncts' needs may be quite different from those of the full-time faculty.

Over half of new adjuncts arrive at universities having never been fully responsible for teaching a course. Their first preparation needs are securing class materials, designing course syllabi, and setting class expectations. They need to develop a sound plan for teaching their courses. Unfortunately, the degree to which institutions meet these course preparation needs varies. Lyons et al. (1999) observed that sometimes institutions provide a course outline, sample syllabus, textbook, and other course materials to the instructor, while in other instances the adjunct is expected to develop a new course with little support or direction. Regardless of the degree of course preparation needed, Lyons et al. and Stone (1996) maintained that part-time faculty members should understand how to set course goals and design clear course objectives based on Bloom's taxonomy of cognitive learning.

Lankard (1993) reported that orientation is crucial in developing faculty loyalty and commitment. O'Banion (1994) noted that part-time faculty need to understand the mission of the institution, and Boice (1992) suggested that thcy also need to understand the expectations the institution has of them, realize how to acclimate to the institution, and grasp the policies and other technical aspects of the institution that affect them. New faculty members also need 
to understand the learner and how to use a variety of instructional strategies. Keim and Biletzky (1999) found in their study of part-time faculty teaching at four community colleges that faculty who participate in development activities are more likely to use a variety of teaching strategies, such as small-group discussions, demonstrations, and activities that promote critical thinking.

Four approaches to faculty support and development have been commonly used for part-time faculty (Approaches to Staff Development, 1986).

- Curriculum development approach: provides for workshops and other courses that help part-timers improve their teaching

- Peer support network approach: enables instructors to turn to each other for help and support

- Personnel management approach: structures policies for effective recruitment, orientation, and staff development

- Adult education: recognizes that as adults, faculty members learn best when their needs are recognized

More vehicles for program delivery exist than ever before. Steinert (2000) noted that faculty development programs can utilize computer-based delivery methods to target the specific needs of individual faculty members, and Gillespie (1998) considered computer-based programs to be appropriate methods for teaching faculty, especially if faculty are to be encouraged to use technology in their classrooms. Killion (2000) noted that a variety of online learning options exist for the delivery of information via the Internet or CD-ROM, ranging from simple email to more sophisticated means such as streaming video, chat rooms, bulletin boards, and online course platforms that provide many functions in one package. Branzburg and Kennedy (2001) found that the best online learning experiences for teachers' professional development employ web-based communication tools such as course email, bulletin boards, and teacher training courses.

\section{The Setting of The Study}

Embry-Riddle Aeronautical University (ERAU) is commitred to promoting teaching effectiveness through faculty development, the use of current technologies and methodologies, and the production of scholarship that tangibly improves teaching. The university seeks to provide all faculty, including its over 2,800 part-time faculty members, with a working environment that fosters professional development and that encourages the use of innovative techniques 
and methodologies, realizing the valuable role that faculty have played in molding the lives of the future leaders of the aviation and aerospace community.

The Extended Campus's mission has been to educate adult students, and the campus has targeted its programs to meet the educational needs of nontraditional undergraduate and graduate students who are usually involved in either the military or industry and seeking education that relates directly to the workplace. The best-qualified individuals to teach these working adults are credentialed professionals involved full-time in industry or the military.

The employment of part-time faculty has provided a number of benefits to Embry-Riddle's Extended Campus. Of paramount significance has been the up-to-date information and relevant, real-life illustrations of textbook concepts that these experts from industry bring to their adult students, and the flexibility in course scheduling. Although most new faculty members have never taught before coming to ERAU, their energy and enthusiasm for their subjects has resulted in generally high teaching evaluations from their students.

At the time of the study in fall 2002, ERAU was a multicampus institution with three distinct campus divisions: two residential campuses and an extended campus. The university served 6,156 undergraduate and 318 graduate students, for a total of 6,474 students on its two residential campuses. ERAU's Extended Campus offered both classroom and online courses and degrees via a network of over 130 teaching centers located throughout the United States and Europe, as well as a large distance learning department. The Extended Campus served an unduplicated annual headcount of 25,801 adult students from fall 2001 to summer 2002 . Of the 4,202 degrees granted to students from all three campuses from June 2001 to July $2002,2,812$ were undergraduate and 1,008 were graduate students.

\section{Design OF THE Study}

The study was conducted as a part of ERAU's Extended Campus's ongoing efforts toward enhancing teaching effectiveness through faculty development. The population of the study was composed of 1,212 part-time faculty members who had taught at least one course for ERAU's Extended Campus from August 15, 2001, to August 15, 2002. A total of 500 part-time faculty members were selected by simple random sample and were mailed surveys. A total of 406 completed surveys ( $81.2 \%$ response rate) were returned. The survey instrument was based on the following dimensions of faculty development: orientation, knowledge of the institution, faculty meetings, content delivery preferences, and the elements of effective teaching. 


\section{Findings OF THE STUdY}

\section{Characteristics of the Institution's Part-Time Faculty}

As ERAU educates students for careers primarily in aviation and aerospace, it was not unexpected to learn that $83.5 \%$ (338) of the part-time faculty members who responded were male. The majority of the respondents were between 40 to 64 years old. Two-thirds of the faculty possessed a master's degree, and almost one-third possessed a doctoral degree. Total years of teaching experience varied, with $18.4 \%$ of the faculty having a total of one to two years of college or university teaching experience, and $15.6 \%$ having 15 or more years of experience. The majority of the part-time faculty (44.6\%) had taught one to two years at ERAU; however, a total of $29.4 \%$ reported teaching for six or more years. A majority of the faculty indicated that they taught for the satisfaction of teaching (56.3\%), while another $17 \%$ taught for the professional experience. An additional $13.5 \%$ reported that their primary motivation was to earn extra income.

\section{Faculty's Orientation to Their Teaching Roles}

The respondents reported that during orientation they were most concerned with understanding the university's academic policies, writing the course syllabus, and gaining access to course materials, and that they were least concerned with how they would teach and the preparation of lesson plans. These findings fit with the needs of new part-time faculty as reported by Roueche et al. (1996b) who stated that providing new part-time faculty with information about the course to be taught and how the course fits into the broader curriculum was very important. The focus of new part-time faculty and those who oriented them to ERAU centered on the immediate concerns of understanding institutional academic policies and the preparation of course materials, while how they would actually teach the course was of less immediate concern.

\section{Part-Time Faculty's Knowledge of the Institution}

Respondents rated the level of importance and their level of understanding of each of the variables that constituted knowledge of the institution: understanding the institution's mission, knowledge of academic programs, knowledge of new events, and knowledge of new policies. The respondents considered understanding the mission of the institution to be most important. Next in importance to the respondents was the need to understand the institutions' academic programs; understanding new policies was also considered somewhat important; and of least importance to the respondents was receiving knowledge of new institutional events. 
A small but statistically significant difference was found between the faculty's level of understanding and ascribed level of importance for each of the following: the institution's mission, the knowledge of academic programs, the knowledge of new events, and the knowledge of new policies. Thus, it was concluded that the part-time faculty valued possessing knowledge of the institution's mission, academic programs, new events, and new policies, and that the faculty would benefit from receiving more information in these areas. It was also concluded that means of communication with the faculty would have to improve to address this need.

\section{Part-Time Faculty's Participation in Faculty Meetings}

The majority of the respondents reported that the benefits of collegial relationships and obtaining current information about ERAU they received from attendance at local faculty meetings was somewhat high or high. The faculty members' perceptions regarding the benefit of atcending faculty meetings in improving their teaching was more varied. One-fourth indicated that the benefit was high; over one-fourth reported that the benefit was somewhat high; and one-fourth reported the benefit was somewhat low. The top three benefits of attending local faculty meetings reported by the participants were forming collegial relationships, obtaining current information about ERAU, and improving their teaching.

Significant differences were found between the benefit of obtaining current information about ERAU at faculty meetings and its importance and between the benefit of improving teaching and its importance. Thus, it was concluded that part-time faculty would benefit from receiving more current information and help in improving teaching at faculty meetings.

Both collegiality and obtaining new information were significant predictors of attendance at faculty meetings, which indicated that these factors were most likely important elements of faculty meetings. Most faculty attended two or three of the four faculty meetings scheduled annually. The most frequently reported hindrance from attending faculty meetings was work responsibilities, with $48.3 \%$ listing this as a factor that prevented attendance. A little over one-fourth indicated that they were never hindered from attending faculty meetings; $8.9 \%$ missed meetings for reasons other than those listed in the survey; $8.6 \%$ missed meetings because of family obligations; $6.9 \%$ reported missing due to a long drive to faculty meetings; and only $1.7 \%$ reported that faculty meetings were not beneficial. 


\section{Expressed Interest in Specific Areas of Professional Development}

Course organization. Almost three-quarters of the respondents reported their level of understanding regarding course organization to be high, while over three-quarters reported their perception of the importance of course organization to be high. Thus, no significant difference between the level of understanding and the level of importance of course organization was found.

Improving student writing. Respondents' understanding of improving student writing was lower than their understanding of course organization. Two-thirds of the faculty rated the importance of improving student writing as high, and one-quarter listed the importance of this area as somewhat high. A significant difference between the level of understanding and the level of importance of improving student writing was found.

Use of technology. Over half of the respondents reported their understanding of using technology in the classroom as high, and one-third considered their understanding to be somewhat high. Over half reported their perception of the importance of using technology in the classroom as high, and over one-third considered their perception to be somewhat high. No signifcant difference between the level of understanding and the level of importance of using technology in the classroom was found.

Assessment of student progress. The respondents appeared confident in their understanding of assessing student progress, with over one-half rating their understanding as high, and one-third indicating their understanding to be somewhat high. Almost three-quarters of the faculty rated their perception of the importance of assessing student progress as high, and the rest indicated their perception to be somewhat high. Thus, a significant difference between the level of understanding and the level of importance in assessing student progress was found.

Accessing library services. The part-time faculty seemed less sure of their understanding of helping students gain access to library services. Only $35.9 \%$ rated their understanding as high in this area, and $41.1 \%$ indicated their understanding as somewhat high. Half rated their perception of the importance of helping students gain access to library services as high, and another $37 \%$ indicated its importance as somewhat high. A significant difference between the level of understanding and the level of importance of helping students gain access to library services was found.

\section{Expressed Interest in and Use of Teaching Strategies}

The faculty were interested in and used class discussion, with two-thirds of the faculty reporting high use and high interest. The next item to receive a large 
number of high ratings was the use of lecture, with almost everyone reporting their use of lecture as either high or somewhat high. The majority indicated a high interest in critical thinking. Simulations, in-class quizzes, and demonstrations were used least and were also less frequently used. Significant differences were found between the levels of use and the levels of interest in class discussion, lecture, critical thinking, writing activities, written feedback, small group discussion, group projects, hands-on activities, simulations, and demonstrations.

The findings indicated that part-time faculty members were interested in learning how to use written feedback in their teaching. They were also interested in learning more about using the teaching strategies of critical thinking, writing activities, group projects, hands-on activities, simulations, and demonstrations. The large number of faculty who did not employ a wide range of teaching strategies also suggested that the part-time faculty would benefit from faculty development activities related to teaching strategies, as Keim and Biletzky (1999) found that faculty who participate in development activities are more likely to use a variety of teaching strategies.

\section{Conclusions and Improvement to Practice}

\section{Orientation to the Teaching Role}

The results of the study indicated that new part-time faculty members' first orientation need is to obtain information on the course to be taught, with help in writing the course syllabus and accessing course resources. The new faculty members needed to understand academic policies, and they needed information on how to organize lesson plans and how to teach.

Interestingly, the faculty reported their need of information on how to teach as lower than the amount of information that they received. However, the faculty's reported use of only a few teaching strategies indicates that they do need more teaching information. Two factors may have influenced the reported low need of teaching information: 1) Concern for the immediate need of preparation as opposed to the more distant need for teaching information, and 2) over-confidence stemming from the common belief, especially of novices, that teaching is a natural ability for which one does not need special instruction. Quite possibly, the new faculty did not realize the benefits of learning how to teach.

As a result of the study, the Center for Teaching and Learning Effectiveness (CTLE) produced a series of online, customizable orientation modules that every new faculty member was required to complete before teaching for ERAU. Four modules were developed: 1) Introduction to Embry-Riddle, 2) 
Preparing to Teach, 3) How to Teach, and 4) and Introduction to Aviation. The appropriate modules were assigned to new adjuncts by their chairs, and the chairs monitored the new instructors' successful completion of the orientation modules.

The Faculty Orientation Manual was also updated to provide the new adjuncts with a hardcopy source of current academic information relevant to their teaching.

\section{Identification With the Institution}

The part-time faculty needed more knowledge of the institution, which would help them to feel more a part of the university. Specifically, the faculty wanted more communication of information in all four areas mentioned in the survey: institutional mission, knowledge of academic programs, knowledge of new events, and knowledge of new programs. As a result of the study, all 3,000 part-time faculty members were given university email accounts and access to the university intranet. This greatly improved the institution's ability to communicate with the part-time faculty members.

Faculty meetings were viewed as beneficial by a majority of the part-time faculty, and the meetings helped the faculty form and maintain collegial relationships. The respondents also reported that obtaining current information about the university and improving teaching were important at faculty meetings. As a result, the CTLE began producing workshops on teaching. A trainthe-trainer approach was used to ensure that all faculty had the opportunity to benefit from the workshop material. The director of CTLE presented the workshops and also provided support materials at the annual regional meetings attended by the center faculty chairs (CFCs), so that the CFCs could tailor the workshop material and present it to their part-time faculty at local faculty meetings.

Both collegiality and obtaining new information were significant predictors of meering attendance. The most frequently reported hindrance from attending faculty meetings was work responsibilities, and over $25 \%$ indicated that they were never hindered from attending faculty meetings. Thus, it appeared that the majority of part-time faculty members perceived the meetings as beneficial, and their reasons for not being able to attend were not related to the quality of the meetings. The addition of the workshop support materials and videos produced by CTLE further enhanced the instructional benefit of attending the meetings. 


\section{Preferred Delivery Methods for Professional Development}

The most preferred delivery methods for professional development were as follows: 1) attending conferences, 2) workshops at faculty meetings, 3) access to course-specific teaching advice on the web, 4) completing teacher training courses online, and (5) receiving email bulletins. The respondents reported needing information to help in improving student writing, assessing student progress, helping students access library services, and using a variety of teaching strategies. Faculty were interested in learning how to use written feedback in their teaching, incorporating critical thinking into their lessons, developing writing activities, directing group projects, providing hands-on activities, creating simulations, and conducting demonstrations. Accordingly, these topics were slated for future workshops.

\section{Implementation of Programs}

As a result of this study, programs to promote the development of the part-time faculty were implemented. Initiatives included producing a video on teaching with technology, providing partial funding for part-time faculty members to present at conferences, and promoting the scholarship of teaching and learning as an activity in which part-time faculty can participate (conducting action research in the classroom and sharing with colleagues at faculty meetings).

An online orientation was developed and became mandatory for all new faculty. Responsibility for the oversight of the orientation was delegated to the center faculty chairs, and the program was very successful in preparing new faculty to teach. Regional faculty meeting agendas were expanded to included at least one teaching and learning presentation or activity that the center faculty chairs could take back to use with the part-time faculty at their centers. Faculty meetings were used to promote part-time faculty members' professional development.

A committee was formed to further investigate ways of meeting the development needs of the adjuncts and to conduct a comparative review of part-time faculty pay. The practice of electing two representatives from the part-time faculty in each of the institution's regions to the faculty senate continued, as the practice was invaluable in providing the institution with the perspective of the adjuncts.

ERAU has made significant progress toward addressing the needs of its adjuncts and remains committed to providing students with well-prepared instructors possessing both academic credentials and industry experience. An institution like ERAU, whose reputation depends on the quality of its adjuncts, must adequately provide for their orientation and development, and meeting their stated needs was instrumental in the successful implementation of the faculty development programs. 


\section{REFERENCES}

American Federation of Teachers. (2002). Standards of good practice in the employment of part-timeladjunct faculty: Fairness and equity. Washington, DC: Author. Retrieved May 9, 2004 from http://www.aft.org/higher_ed/images/Booklet.pdf

Approaches to staff development for part-time faculty. (1986, July 1). ERIC Digest. (ERIC Document Reproduction Service No. ED270180). Retrieved May 9, 2004, from http://www.ericfacility.net/databases/ERIC_Digests/ed270180.html

Bensimon, E. M., Ward, K., \& Sanders, K. (2000). The department chair's role in developing new faculty into teachers and scholars. Bolton, MA: Anker.

Boice, R. (1992). The new faculty member. San Francisco, CA: Jossey-Bass.

Branzburg, J., \& Kennedy, K. (2001, September). Online professional development. Technology and Learning, 22(2), 18-27.

Breneman, D. W. (2002, July 14). For colleges, this is not just another recession. Chronicle of Higher Education, p. B7.

Eble, K. E., \& McKeachie, W. J. (1985). Improving undergraduate education through faculty development. San Francisco, CA: Jossey-Bass.

Fulton, R. D. (2000, May). The plight of part-timers in higher education. Change, $32(3), 38-42$.

Gaff, J. G. (1975). Toward faculty renewal: Advances in faculty, instructional, and organization development. San Francisco, CA: Jossey-Bass.

Gappa, J. M. (1984). Part-time faculty: Higher education at a crossroads (ASHE-ERIC Higher Education Research Report No. 3). Washington, DC: Association for the Study of Higher Education.

Gappa, J. M., \& Leslie, D. W. (1993). The invisible faculty: Improving the status of part-bimers in higher education. San Francisco, CA: Jossey-Bass.

Gillespie, K. H. (Ed.). (1998). The impact of technology on faculty development, life, and work. New directions for teaching and learning: No. 76. The impact of technology on faculyy development, life, and work. San Francisco, CA: Josscy-Bass.

Haeger, J. D. (1998). Part-time faculty, quality programs, and economic realities. In D. W. Leslie (Ed.), New directions for higher education: No. 104. The growing use of part-time faculty: Understanding causes and effects (pp. 81-88). San Francisco, CA: Jossey-Bass.

Jacobs, F. (1998). Using part-time faculty more effectively. In D. W. Leslie (Ed.), New directions for higher education: No. 104. The growing use of part-time faculty: Understanding causes and effects (pp. 9-17). San Francisco, CA: Jossey-Bass. 
Keim, M. C., \& Biletzky, P. (1999, December). Teaching methods used by part-time community college faculty. Community College Journal of Research of Practice, 23, 727-737.

Killion, J. P. (2000, Summer). Log on to learn. Journal of Staff Development, 21(3), 48-53.

Lankard, B. A. (1993). Part-time instructors in adult and vocational education. Columbus, OH: ERIC Clearinghouse on Adult, Career, and Vocational Education. (ERIC Reproduction Service No ED363797)

Leslie, D. W. (1998). New directions for research, policy development, and practice. In D. W. Leslie (Ed.), New directions for higher education: No. 104. The growing use of part-time faculty: Understanding causes and effects (pp. 95-100). San Francisco, CA: Jossey-Bass.

Lyons, R. E., Kysilka, M. L., \& Pawlas, G. E. (1999). The adjunct professor's guide to success. Boston, MA: Allyn and Bacon.

O'Banion, T. (1994). Teaching and learning in the community college. Washington, DC: Community College Press.

Roueche, J. E., Roueche, S. D., \& Milliron, M. D. (1995). Strangers in their own land: Part-time faculty in American community colleges. Washington, DC: Community College Press.

Roueche, J. E., Roueche, S. D., \& Milliron, M. D. (1996a, Spring). Identifying the strangers: Exploring part-time faculty integration in American community colleges. Community College Review, 23(4), 33-48.

Roueche, J. E., Roueche, S. D., \& Milliron, M. D. (1996b, March). In the company of strangers: Addressing the utilization and integration of part-time faculty in American community colleges. Community College Journal of Research and Practice, 20(2), 105-117.

Steinert, Y. (2000, January). Faculty development in the new millennium: Key challenges and future directions. Medical Teacher, 22, 44-50.

Stone, T. E. (1996). Developing instructional objectives, lesson plans, and syllabi. In V. Bianco-Mathis \& N. Chalofsky (Eds.), The adjunct faculty handbook (pp. 28-39). Thousand Oaks, CA: Sage.

Wunsch, M. A. (1994). New directions for mentoring: An organizational development perspective. In M. A. Wunsch, R. J. Menges, \& M. D. Svinicki (Eds.), New directions for teaching and learning: No. 57. Mentoring revisited: Making an impact on individuals and institutions (pp. 9-13). San Francisco, CA: Jossey-Bass. 
Wyles, B. (1998). Adjunct faculty in the community college: Realities and challenges. In D. W. Leslie (Ed.), New directions for higher education: No. 104. The growing use of part-time faculty: Understanding causes and effects (pp. 89-93). San Francisco, CA: Jossey-Bass. 